\title{
Feline Lymphoma
}

National Cancer Institute

\section{Source}

National Cancer Institute. Feline Lymphoma. NCI Thesaurus. Code C132193.

A lymphoma that occurs in cats. It is associated with exposure to feline leukemia virus and feline immunodeficiency virus. 